\title{
Comparing Receptive and Productive Academic Vocabulary Knowledge of Chinese EFL Learners
}

\author{
Songbo Zhou \\ School of International Studies, Zhejiang University \\ 388 Yuhangtang Road, Hangzhou 310058, Zhejiang, China \\ Tel: 86-571-8820-6256_E-mail: songbo827@hotmail.com
}

\begin{abstract}
Vocabulary acquisition has been a major concern of English teachers and learners. Much research has been done to examine vocabulary knowledge of Chinese EFL learners, but little has done so far on academic vocabulary. The study reported in the paper sets out to investigate the receptive and productive academic vocabulary knowledge of Chinese EFL learners. Results indicate that Chinese EFL learners have a larger receptive academic vocabulary size and productive academic vocabulary size and the two sizes are moderately correlated. Implications of the study results for vocabulary instruction are then discussed.
\end{abstract}

Keywords: Receptive vocabulary, Productive vocabulary, Academic vocabulary, Chinese EFL learner, Academic Word List

\section{Introduction}

Since the past few decades, English has become increasingly important in China. English is a compulsory subject since Grade 3 of all elementary schools with suitably qualified English teachers. English also plays a major role in college admission decisions and promotional decisions in the workplace. In light of this, numerous English teaching materials and courses have been developed in order to meet the diverse needs of Chinese EFL learners. In designing the course, teaching materials and syllabus, it is crucial for the designers to gain a clear idea of learners' language proficiency, especially their vocabulary knowledge. For example, the latest national "College English Curriculum Requirements" (2007) was preceded by national surveys of English vocabulary size. The Requirements also clearly define the goal of vocabulary learning at college level as a total of 6,674 words (including 2,354 active words) and 1875 phrases.

Nation (2001) divided vocabulary into four categories: high frequency words, academic words, technical words, and low frequency words. The most commonly used list of high frequency words is General Service List of English Words (GSL), by West (1953), which includes around 2,000 word families. They cover about $80 \%$ of the running words in academic texts. Technical words refer to types of words that usually occur in a specific subject area. They differ from subject area to subject area and cover about $5 \%$ of the running words in a text. Academic vocabulary is the vocabulary used across all academic disciplines but is not the technical vocabulary of a particular academic discipline. Academic words are based on more Latin and Greek roots than most everyday spoken words. They cover about $10 \%$ of the running words in an academic text. This means that knowing the 2,000 high frequency words plus academic words will give about $90 \%$ coverage of the running words in academic texts. The last category is low frequency words. They are the biggest groups of words but only cover about $5 \%$ of the running words in an academic text.

Much research has been done to measure vocabulary knowledge of Chinese EFL learners. For example, Ma (2001) and Zhou \& Wen (2000) tracked the vocabulary growth of science students in Chinese colleges. Shao (2002) investigated the vocabulary size of students of normal colleges in China. Xiao (2007) investigated breadth and depth of vocabulary knowledge of 168 college students. In the vocabulary assessments reported so far, the tested words were mostly sampled from the word list included in "College English Curriculum Requirements", which was based on words' frequency, coverage and range. So far, no research has yet been done specifically on academic vocabulary knowledge of Chinese EFL learners. In light of this, the paper reports a comparative study on the receptive and productive knowledge of academic vocabulary of Chinese college EFL learners. The purpose of this study is to gain an insight into the academic vocabulary knowledge of Chinese college EFL learners, with implications for college English teaching and learning. 


\section{An Academic Word List}

Two most commonly cited academic word lists are University Word List (UWL), by Xue \& Nation (1984), and Academic Word List (AWL), by Coxhead (2000). Both lists contain words that do not occur in the General Word List but occur frequently across a wide range of academic texts. However, the AWL is a great improvement on the UWL. First, the UWL has 836 word families and covers $9.8 \%$ of the 3.5 million-word corpus of academic texts. The AWL has 570 word families and covers $10 \%$ of the corpus. Therefore, the AWL, though smaller, provides a wider coverage of academic texts than the UWL. Second, the UWL "lacked consistent selection principles and had many of the weakness of the prior work" (Coxhead, 2000, P. 214). The AWL, however, was based on a corpus made up of academic texts in four disciplines: arts, commerce, law and science. The selection of words was based on three criteria: non-occurrence in the GSL; a minimum of 10 occurrences in each section of the corpus; and a minimum frequency of 100 in the academic corpus.

\section{Receptive vs. Productive Vocabulary Knowledge}

One very important dimension of vocabulary knowledge is receptive vs. productive vocabulary knowledge. Receptive vocabulary knowledge refers to the ability to understand a word when it is heard or seen while productive knowledge is the knowledge to produce a word when one writes or speaks. It is generally believed that words are known receptively first and only after intentional or incidental learning become available for productive use. Therefore, vocabulary knowledge should be regarded as a continuum on which a word grows from receptive to productive status. Although little is know till now about the transfer from receptive to productive mastery, it is generally believed that learners' receptive vocabulary size is much larger than their productive vocabulary size.

\section{The Study}

The present study sets out to investigate the receptive and productive academic vocabulary knowledge of Chinese EFL learners and discuss implications for academic vocabulary instruction in college.

\subsection{Subjects}

A total of 72 Chinese non-English major college students took part in the study. They were grouped into the same level according to their performance in a language proficiency test when they first entered the college. They had taken the same English course for 7 months. Therefore they could be considered as students with about the same proficiency level. These students were a mixture of science and arts students.

\subsection{Tests}

Receptive vocabulary was measured by using the academic section of the Vocabulary Levels Test developed by Schmitt et al. (2001). The test has 30 items in 10 clusters. It is based on Academic Word List, rather than the outdated University Word List. In the test, learners are asked to match three of the six words on the left with the definitions given on the right, as shown below.

$\begin{array}{ll}1 & \text { business } \\ 2 & \text { clock } \\ 3 & \text { horse } \\ 4 & \text { pencil } \\ 5 & \text { shoe } \\ 6 & \text { wall }\end{array}$

part of a house animal with four legs something used for writing

As to the assessment of productive vocabulary, the existing productive version of the academic section of the Vocabulary Levels Test is based on the University Levels Test and contains only 18 items. Therefore, it is necessary to design a new productive vocabulary test that is based on the Academic Word List and contains 30 items. In this way, results from receptive and productive vocabulary size tests can be comparable and the reliability can be increased greatly. In light of this, a new productive vocabulary test was developed in this study. It measured the same 30 words tested in a parallel version of the receptive vocabulary levels test that was used in this study. And it followed the same format of the vocabulary size test of controlled productive ability developed by Laufer and Nation (1999), shown below. For each item in the test, a meaningful sentence context was presented and the first few letters of the target words were given to the learners. The purpose of providing the first few letters was to prevent learners from filling in the sentence with another word which would be both grammatically and semantically correct but which comes from a different frequency level.

In order to be accepted into the university, he had to impr his grades. 


\subsection{Grading of the tests}

Two vocabulary size tests, one receptive and one productive, were administered on a total of 72 non-English major college students in China. The grading of the receptive test was done in terms of correct/incorrect for each item. The grading of the productive test was done in terms of correct, partially correct, and incorrect. One point was awarded to every correct answer. Half a point was awarded to every partially correct answer. For the productive test, grammatical mistakes were ignored and minor spelling mistakes were marked as partially correct. The decision made on those partially correct answers was based on the pronunciation of the answers. If the misspelled answer had the same or about the same pronunciation as the target word, it was regarded as partially correct. For example, if the target word was "philosophy" but the student misspelled the word as "phylosophy", the answer was marked as partially correct. The grading of the receptive test was done by one teacher and that of the productive test was done separately by two teachers.

\subsection{Results and discussion}

Statistical analysis was done on the scores. The mean for receptive academic vocabulary size test was 23.444 compared with 10.604 for productive vocabulary size test. This indicates that non-English major college students know more academic vocabulary receptively than they do productively. This is not surprising since much research on the comparison between receptive and productive vocabulary knowledge reveals that the development of productive vocabulary knowledge lags far behind that of receptive knowledge. The first step in learning a word is often to be able to recognize a word by its form and understand what it means. Then gradually, with more practice of this word in reading, listening, writing, or some other activities, learners increase their knowledge of this word and learn to use the word productively in writing or speaking. Therefore, it is apparent that productive vocabulary knowledge builds on receptive knowledge.

\section{Insert Table 1 Here}

Table 2 shows the correlations between the receptive academic vocabulary size test and the productive one. The receptive test correlated .617 with the productive test which was significant at the .001 level. This means that one's receptive academic vocabulary knowledge correlates with their productive knowledge.

\section{Insert Table 2 Here}

The subjects were also divided into two groups according to their scores on the receptive academic vocabulary size test. Subjects whose score on the receptive test was higher than the average (23.444) were regarded as Group 1. And those whose score was below the average were in Group 2. Then statistical analysis was also done to examine the correlation between the two groups of students in their test scores of two tests. Table 3 and 4 present descriptive statistics of Group 1 and correlations between their two test scores. Table 5 and 6 present descriptive statistics of Group 2 and correlations between their two test scores.

\section{Insert Table 3 Here}

\section{Insert Table 4 Here}

Insert Table 5 Here

\section{Insert Table 6 Here}

Results indicate that students with a larger receptive academic vocabulary size tend to have more productive academic knowledge. Besides, the correlation between the two tests was higher for Group $2(0.595)$ than that for Group 1 (0.446). This indicates that receptive academic knowledge grows at a higher rate than productive knowledge.

\section{Implications for Academic Vocabulary Teaching}

In conclusion, the study shows that Chinese non-English college students have a larger receptive academic vocabulary size than productive one and their receptive and productive academic vocabulary knowledge are correlated. The results of the study reported in the paper have implications for the teaching and learning of academic vocabulary in China. College English teaching used to be characterized by grammar and translation. With the new college English curriculum, increasingly more importance has been laid on the development of communicative skills and the ability to exchange information effectively through both spoken and written channels. As a result, the pedagogical approach to English teaching shifts to communicative language teaching. Classroom instruction is largely meaning-centered and little attention is directed to language form. However, it has now become evident that second language learners could not achieve high levels of linguistic competence from entirely meaning-centered instruction. This is true both for grammar learning and vocabulary learning. When reading a text, listening to news, or discussing a topic, learners may incidentally learn some words or 
phrases. But the vocabulary is not learned in depth. In other words, learners may acquire, through communicative tasks, a large number of words that they are able to recognize but could not use productively. Therefore, words that learners can recognize are far more than those that learners can use productively. This is especially true for academic vocabulary which are not in the General Service List but occur reasonably frequently over a wide range of academic texts. In most colleges in China, academic English vocabularies are usually learned through extensive reading both in and out of class. Therefore, knowing a word often means knowing the meaning of the word when it is encountered in the reading text.

In order to improve learners' academic vocabulary knowledge in terms of both receptive and productive abilities, it is very important to combine learning vocabulary incidentally through communicative activities with explicit vocabulary learning. One example of an explicit strategy for vocabulary acquisition is learning words from a list. Recent research reveals that list learning of L2 vocabulary can be a very efficient means of L2 vocabulary acquisition. Thornbury (2002) states that the value of list learning may have been underestimated and suggests several techniques for effectively using word lists in the classroom. Take academic vocabulary for example. Teachers can make full use of the Academic Word List. Since the AWL is divided into 10 sublists of word families, teachers can ask students to work on one sublist for every few weeks. By explicitly learning different aspects of words (such as their meanings, forms, and collocations) and being exposed to these words in other areas of their course work, students will gradually be able to use them receptively and productively. Teachers may also include some vocabulary enhancement activities in language classes. For example, retelling stories, problem solving and information transfer activities are all very useful for students to learn to use words productively. Besides, teachers should make students fully aware of the importance of academic vocabulary and design activities especially for the practice of academic vocabulary.

\section{References}

Coxhead, A. (2000). A new academic word list. TESOL Quarterly, 34 (2), 213-238.

Department of Higher Education, Ministry of Education. (2007). College English Curriculum Requirements. Beijing: Foreign Language Teaching and Research Press.

Laufer, B. \& Nation, P. (1999). A vocabulary size test of controlled productive ability. Language Testing, 16(1), 33-51.

Ma, G.. (2001). The Study of the College English Vocabulary Proficiency of Chinese Tertiary-level Students. Foreign Language Education, 22(2), 48-52.

Nation, I. S. P. (2001). Learning vocabulary in another language. Cambridge: Cambridge University Press.

Schmitt, N., Schmitt, D., \& Clapham, C. (2001). Developing and exploring the behavior of two new versions of the Vocabulary Levels Test. Language Testing, 18 (1), 55-88.

Shao, H. (2002). An empirical study of College English vocabulary proficiency of Chinese normal college students during Band 1-4 stage. Foreign Language Teaching and Research, 34(6), 421-425.

Thornbury, S. (2002). How to Teach Vocabulary. Pearson Education Limited.

West, M. (1953). A General Service List of English Words. Longman, London.

Xiao, L. (2007). Assessing the roles of breadth and depth of vocabulary knowledge in second language proficiency. Foreign Language Teaching and Research, 39(5), 352-359.

Xue, G., \& Nation, I. S. P. (1984). A university word list. Language Learning and Communication, 3, 215-229.

Zhou, D \& Wen, B. (2000). A track investigation of English vocabulary of Chinese college students. Foreign Language Teaching and Research, 32(5), 356-361. 
Table 1. Descriptive statistics of the two academic vocabulary size tests

\begin{tabular}{|c|c|c|c|c|c|}
\hline & N & Minimum & Maximum & Mean & Std. Deviation \\
\hline Receptive voc. & 72 & 10.0 & 30.0 & 23.444 & 4.4781 \\
Productive voc. & 72 & 1.0 & 19.5 & 10.604 & 4.3645 \\
Valid N (listwise) & 72 & & & & \\
\hline
\end{tabular}

Table 2. Correlations between the receptive academic vocabulary test and the productive test

\begin{tabular}{|cc|c|c|}
\hline & & Receptive voc. & Productive voc. \\
\hline & Pearson Correlation & 1 & $.617^{* *}$ \\
Receptive voc. & Sig. (2-tailed) & & .000 \\
& $\mathrm{~N}$ & 72 & 72 \\
\hline & Pearson Correlation & $.617^{* *}$ & 1 \\
Productive voc. & Sig. (2-tailed) & .000 & \\
& $\mathrm{~N}$ & 72 & 72 \\
\hline
\end{tabular}

**. Correlation is significant at the 0.01 level (2-tailed).

Table 3. Descriptive statistics of the two academic vocabulary size tests of Group 1

\begin{tabular}{|c|c|c|c|}
\hline & Mean & Std. Deviation & N \\
\hline receptive vocabulary & 26.895 & 2.0106 & 38 \\
productive vocabulary & 12.3816 & 4.18884 & 38 \\
\hline
\end{tabular}

Table 4. Correlations between two tests of Group 1

\begin{tabular}{|cc|c|c|}
\hline & & $\begin{array}{c}\text { receptive } \\
\text { vocabulary }\end{array}$ & $\begin{array}{c}\text { productive } \\
\text { vocabulary }\end{array}$ \\
\hline receptive vocabulary & Pearson Correlation & 1 & $.446^{* *}$ \\
& Sig. (2-tailed) & & .005 \\
$\mathrm{~N}$ & 38 & 38 \\
\hline & Pearson Correlation & $.446^{* *}$ & 1 \\
productive vocabulary & Sig. (2-tailed) & .005 & \\
& $\mathrm{~N}$ & 38 & 38 \\
\hline
\end{tabular}

**. Correlation is significant at the 0.01 level (2-tailed). 
Table 5. Descriptive statistics of the two academic vocabulary size tests of Group 2

\begin{tabular}{|l|c|c|c|}
\hline & Mean & Std. Deviation & $\mathrm{N}$ \\
\hline receptive vocabulary & 19.588 & 3.0956 & 34 \\
productive vocabulary & 8.618 & 3.6888 & 34 \\
\hline
\end{tabular}

Table 6. Correlations between two tests of Group 2

\begin{tabular}{|cc|c|c|}
\hline & & $\begin{array}{c}\text { receptive } \\
\text { vocabulary }\end{array}$ & $\begin{array}{c}\text { productive } \\
\text { vocabulary }\end{array}$ \\
\hline receptive vocabulary & Pearson Correlation & 1 & $.595^{* *}$ \\
& Sig. (2-tailed) & & .000 \\
$\mathrm{~N}$ & 34 & 34 \\
\hline & Pearson Correlation & $.595^{* *}$ & 1 \\
productive vocabulary & Sig. (2-tailed) & .000 & 34 \\
& $\mathrm{~N}$ & 34 & \\
\hline
\end{tabular}

**. Correlation is significant at the 0.01 level (2-tailed). 